\title{
A Survey on Fauna of Fleas (Order: Siphonaptera) of Cow and Sheep in Southern Khorasan-e-Razavi Province, Iran
}

\author{
Hamed Ramezani Awal Riabi ${ }^{1}$; Alireza Atarodi ${ }^{2, *}$ \\ ${ }^{1}$ Deputy of Health, Gonabad University of Medical Sciences, Gonabad, IR Iran \\ ${ }^{2}$ Department of Basic Sciences, Gonabad University of Medical Sciences, Gonabad, IR Iran \\ *Corresponding author: Alireza Atarodi, Department of Basic Sciences, Gonabad University of Medical Sciences, Gonabad, IR Iran. E-mail: aratarodi1387@yahoo.com
}

Received: February 5, 2014; Accepted: June 20, 2014

\begin{abstract}
Background: Fleas are wingless insects belonging to the Siphonaptera order (named because of their siphon-like mouthparts).
Objectives: The aim of this study was to evaluate the abundance and fauna of the fleas that are the carrier pathogen in the South of Khorasan-e-Razavi province.

Materials and Methods: In this cross-sectional study, for catch the fleas of cow and sheep were used 3 methods such as: light trap, sticky trap, and human bite.

Results: A total number of 580 fleas from Gonabad and Bajestan cities were collected that all species were Pulex iritans. Thirty five percent fleas were collected from cow and $65 \%$ from sheep.

Conclusions: Considering that fleas are carrier pathogens and tend to feed on human blood, which is offered periodically at different seasons, barn spraying with appropriate insecticide was performed.
\end{abstract}

Keywords: Siphonaptera; Fauna; Iran

\section{Background}

Fleas are wingless insects belonging to the Siphonaptera order (named because of their siphon-like mouthparts). There are nearly 2000 species of fleas (95\%) found on mammals, but fewer species can be found on birds and other hosts [1]. Ectoparasitism is a very serious threat to both animals and humans all over the world caused by parasites that live on the surface of the host that are called ectoparasites (e.g. some mites). The parasites bites are so painful that could make a great nuisance and can also lead to loss of large amount of Fleas' blood and form a unique group of insects called Order Siphonaptera [2]. The evolutions of these species had taken place in the early Cretaceous or Jurassic age with the evolution of marsupials and insectivores about 125 to 150 million years ago. Historically, one of the most important ectoparasites of humans is the parasites called fleas that are the natural vectors of several important infectious diseases, like plague. Some 15 families with a total of 220 genera and some 2,500 species of the fleas can be distinguished today in the world [2]. Most fleas of veterinary importance are grouped in the family's Pulicidae, Ceratophyllidae, Leptopsyllidae and Vermipsyllidae. Rarely, members of other families (Hystrichopsyllidae, Rhopalopsyllidae) may be found on domestic animals [1].

Ctenocephalides felis is the species that most commonly infests dogs and cats and the less common species include Ctenocephalides canis, Echidnophaga gallinacea and
Pulex simulans. Occasionally, the odd rodent or rabbit' flea will be found on pets that prey on or scavenge rodents or rabbits [3]. Flea-borne zoonoses such as plague (Yersinia pestis) and murine typhus (Rickettsia typhi) caused significant numbers of human cases in the past and remain a public health concern. Other flea-borne human pathogens have emerged recently (e.g. Bartonella henselae, Rickettsia felis), and their mechanisms of transmission and impact on human health are not fully understood. P. irritans (Pulex irritans), also called the human flea, is not often seen in contemporary living quarters, but in the past this flea came in contact with all classes of people [4].

Human blood is the preferred food of P. irritans, but it will feed on other mammals. Today, this species are the most often found on pigs. Individuals that work with swine are some of the most likely people to become infested. In societies where personal hygiene is important, infestations by human fleas are not as common [5]. Human fleas were extremely common before the development of modern standards in both hygiene and laundering. Most fleas, during that time, were found in a person's bedding. In an attempt to decrease infestation, the Chinese placed warmed flea traps made of ivory or bamboo between the sheets before going to bed at night. During the Renaissance period, ladies frequently wore fur collars, called cravats, to catch the pestering fleas. The cravat could then be removed and shaken out to decrease the

Copyright (C) 2015, Zahedan University of Medical Sciences. This is an open-access article distributed under the terms of the Creative Commons Attribution-NonCommercial 4.0 International License (http://creativecommons.org/licenses/by-nc/4.0/) which permits copy and redistribute the material just in noncommercial usages, provided the original work is properly cited. 
chance of coming in contact with any fleas. P. irritans is mainly a nuisance to humans [3].

Given that, fleas are caught, this study is the vectors of plague and typhus, and on the other hand, due to anthropophilic (philanthropy) than the humans that cause human Harassment be testing resistance to pesticides and proper spraying is necessary to control arthropod.

\section{Objectives}

This study has been conducted in the southern cities of Khorasan-e-Razavi province from September to November 2012 years in order to identify the best way to fight these arthropod in the villages in which the greatest total of livestock are found.

\section{Materials and Methods}

This study is a descriptive-cross sectional study performed in cities of Gonabad and Bajestan in South of Khorasan-e-Razavi province with an area of 10,000 square kilometers in the desert area, these cities are located between Southern Khorasan and Sistan and Balouchestan provinces faced with the risk of some arthropods with animals that are passing through. Sampling and species identification. In this study, a total of 45 villages were randomly selected from 110 villages using random numbers table that in each village some animals, husbandries were selected randomly for collecting the fleas from a total of 50 cows and 600 sheep. For collecting the samples of March to August 2013, three methods of sticky traps, human bait and light traps were used.

In a sticky trap, white cloth impregnated with castor oil connected to a timber one meter length and behind the bag there was a plastic water bag with 35 degrees, and then the trap was moved in the floor and at the side walls of the barn. In human bait method a white cloth impregnated with castor oil wrapped to a volunteered feet and then the person was moving into the barn, so the fleas that were caught in this way were transported to the laboratory for identification and sampling a vial of alcohol $70 \%$ and in the third sampling method a 12 volt bulb that was connected to an adapter and a pot of water was put under it, then was turned on in the barn and the next morning floating fleas were collected and transported to the laboratory.

The collected fleas in three methods were transferred in separate vials containing alcohol 70\% ethanol depending on cow and labeled village name, type of livestock and collecting date to the laboratory. In the laboratory collected fleas of animals in each region were caught separately and were poured in a container $\mathrm{KOH}$ was left at room temperature for 24 hour. Then the fleas were poured in a container with glasyal acetic acid for 1 hour and later to dewater anthropod, the samples were transferred to a container of alcohol of 50, 80, and 96 for 30-60 min. After finishing the stages, the fleas were transferred to Poori and were fixed. For identifying the key of Harry D. Prat, 1954 was used.

\section{Results}

In total 580 fleas were collected from 45 rural areas in both Gonabad and Bajestan cities and all were from P. iritans species. Thirty five percent fleas were collected from cow and $65 \%$ from sheep that 53.2 from male and 46.8 were female cows, whereas $54.8 \%$ from ram and $45.2 \%$ were from female sheep. Fifty seven point four percent fleas were collected by human bait method and the least were collected by using light traps (18.6\%). Seventy five percent of the collected fleas were collected by human bait method from sheep that the male to female ratio of fleas, 1.5 against. Data were analyzed using SPSS- 16 and $\chi^{2}$ test. In the first two seasons of the year, due to the effects of temperature on growth and reproduction fleas, most fleas were captured in the summer (63.7\%). Figure 1 shows abundance of fleas caught in Spring and Summer 2013, also Tables 1 and 2 show frequency of the fleas sampling.

Table 1. Frequency of the Fleas Sampling According to Geographical Area and Type of Domestic Animal

\begin{tabular}{|c|c|c|c|c|}
\hline \multirow[t]{3}{*}{ Sampling areas } & \multicolumn{4}{|c|}{ Type of Animal } \\
\hline & \multicolumn{2}{|c|}{ Cow } & \multicolumn{2}{|c|}{ Sheep } \\
\hline & Male & Female & Male & Female \\
\hline Haji Abad & 20 & 34 & 0 & 0 \\
\hline Zirjan & 10 & 8 & 117 & 113 \\
\hline Behabad & 25 & 8 & 16 & 15 \\
\hline Nodehmirmehrab & 17 & 6 & 7 & 5 \\
\hline Fodanjan & 10 & 6 & 9 & 10 \\
\hline Pachk & 2 & 2 & 7 & 9 \\
\hline Mend & 3 & 2 & 7 & 9 \\
\hline Jazin & 4 & 6 & 9 & 5 \\
\hline Ohnak & 8 & 5 & 7 & 6 \\
\hline Zibad & 5 & 6 & 14 & 9 \\
\hline Roshnavand & 4 & 13 & 0 & 0 \\
\hline Total & 108 & 95 & 193 & 184 \\
\hline
\end{tabular}


Ramezani Awal Riabi H et al.

Table 2. The Frequency of Fleas Sampling According to Sampling Method and Domestic Type of Animal

\begin{tabular}{lccccc}
\hline Sampling Method & \multicolumn{3}{c}{ Type of Animal } \\
\cline { 2 - 6 } & & Cow & Sheep \\
\cline { 2 - 6 } & Male & Female & Male & Female \\
\hline Light Trap & 60 & 10 & 65 & 20 \\
Sticky Trap & 30 & 20 & 180 & 24 \\
Human bait & 50 & 33 & 233 & 100 \\
Total & 140 & 63 & & 144 \\
\hline
\end{tabular}

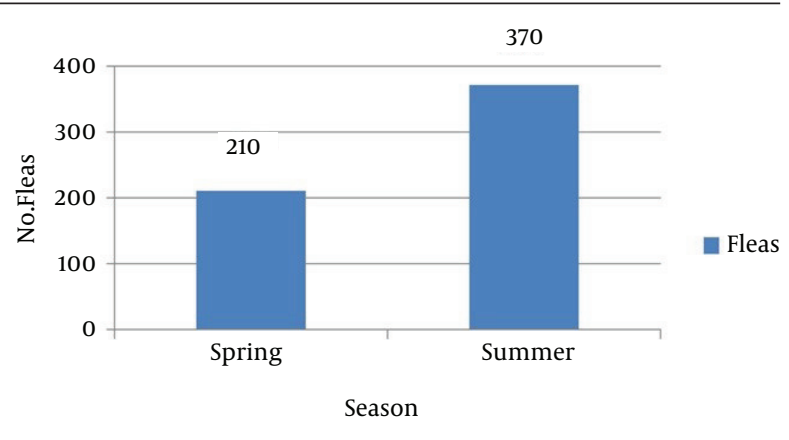

Figure 1. Abundance of Fleas Caught in Spring and Summer 2013

\section{Discussion}

One of the major health problems in the study areas, harassing humans is fleas' bites that usually stop him from rest and relaxation and cause allergic status on him associated with intense itching sensation. P. irritans was the two dominant species in most rural areas of these two cities. This flea lacks head, pronotal comb (cetenidia) and its head is rounded in front and the total of 3 thorax segments is equall with the first segment of its abdomen or more than length. Mesopleuron lacks meral rod.

The best method used for collecting them was human bait and since the collected species tend to blood-feeding from human were more attracted to human but in light trap method they were less attracted to light since they need a provocation by animal or human to move. In sticky traps because of using the water content bag of 36 degrees that was close to the human body temperature, fleas' attraction was more in compare to the light trap method. Highest fleas collected from the village Zyrjan (40.1\%) and the lowest was from the village Roshnavnd (2.9\%) due to how stable spraying in two villages.

In Khoobdel et al. study conducted in Kohkiluyeh and Boyerahmad, 2435 fleas were collected that $36.9 \%$ by paper trap method, $24 \%$ with human bait and $16.4 \%$ were collected by light traps [6]. Faunistic study of fleas has been started about 50 years ago in Iran during which, the fleas' fauna and ecology have been studied in Iran's Kurdish region or at the heart of Plague natural region and in addition several new species of the insects have been reported elsewhere in Iran [7]. A total of 66 species of fleas have been introduced in Iran. Some studies have been performed In Kermanshah, Lorestan and Bandar Abbas on the rodents' fleas that P. irritans has been observed among the reported fleas [8].

In a study performed in Tanzania from 1986 to 2004, 12 villages were surveyed for infected domestic animals with fleas that in 7 villages $P$. irritans fleas were considered to have severe infection to Yersinia pestis that shows the importance of controlling this arthropod, but in our study did not survey infection fleas [5]. In another study performed from June to July 2002 in Greece on domestic animals such as cattle, sheep and goats, all collected fleas were Polex species. Prevalence of ectoparasitic arthropods in sampled groups of wild ( $n=128 ; 16$ species) and domestic ( $n=69 ; 3$ species) animals in the Las Merindades area of the province of Burgos, Spain. The overall prevalence of parasitisation by fleas was $27 \%$. Ctenophthalmus spp. showed the wider range of host in wild animals, while $P$. irritans was the most frequent species in domestic animal [9] in this study, as in our study, most fleas collected were $P$. irritans and over the cattle and sheep. A plague that was epidemic in an area of Tanzania in 1980 caused many cases of death. Epidemiological studies and active surveillance were conducted from June 1980 to May 1990. All rodents were collected by live rodent trap and fleas by light trap and were identified. Most of the fleas of houses were P. irritans and resistant to the used pesticides [10].

A study was carried out on the contamination of domestic livestock with fleas in northern Libya. From 1861 surveyed animals, 1857 Ctenocephalides felis and $4 \mathrm{Pu}$ lex irritans and also from 79 visited dogs 53 cases were infected to P. irritans. With this approach, the human flea has a worldwide spread and can feed on most of domestic animals maintained in human environment and be easily transferred to different locations [11]. In a breeder farm near Tehran, severe infestation to fleas was observed. Morphological characteristics of the flea were those related to human flea P. irritans. Although based on reports, the severity of infestation in some hall was to the extent that the farm workers and even the dwellers around the farm were severely infested [12]. In a study performed on sheep fleas in Isfahan showed that from 905 collected fleas $98.3 \%$ were P. irritans and $1.7 \%$ were Ctenocephalides canis, this result is in accordance 
with our study results [13]. Considering the present study results it is suggested for combating the fleas to spray clothing of non-native individuals who are more sensitive to the fleas bites with proper pesticides and on arrival to the animal barn put pants into socks to prevent their entrance to person's clothing and also pour soil mixed with pyrethroid inside the barn at the edge of the walls and the barn environment be heated with flame once a year. Considering that fleas are caught tend to feed on human blood, which is offered periodically at different seasons, be done, barn spraying with appropriate insecticide.

\section{Acknowledgements}

The authors would like to appreciate very much for kind collaboration of health staffs in public health center of Gonabad. The code of project is 1.359 and said authors provided the research.

\section{Authors' Contributions}

All authors had equal role in design, performing, statistical analysis and manuscript writing.

\section{Funding/Support}

This research was performed in personal cost.

\section{References}

1. Dobler G, Pfeffer M. Fleas as parasites of the family Canidae. Parasit Vectors. 2011;4:139.
2. Durden LA, Hinkle NC. Fleas (Siphonaptera). In: Mullen GR, Durden LA, editors. Medical and veterinary entomology. 2 th ed. San Diego, USA: Academic Press; 2009. 115-36.

3. Natala AJ, Okubanjo OO, Ulayi BM, Owolabi YN, Jatau ID, Yusuf $\mathrm{KH}$. Ectoparasites of domestic animals in Northern Nigeria. $J$ Anim Plant Sci. 2009;3(3):238-42.

4. Anisimov AP, Lindler LE, Pier GB. Intraspecific diversity of Yersinia pestis. Clin Microbiol Rev. 2004;17(2):434-64.

5. Laudisoit A, Leirs H, Makundi RH, Van Dongen S, Davis S, Neerinckx S, et al. Plague and the human flea, Tanzania. Emerg Infect Dis. 2007;13(5):687-93.

6. Khoobdel M, Shayeghi M, Alamdar K. Fauna and the relative frequency of medically important fleas in the rural areas of Kohgiloye-va-Boyerahmad, Iran. J Sch Pub Health Inst Pub Health Res. 2011;9(3): 63-72.

7. Farhang-Azad A. The flea fauna of Iran. XI. Iranian species of the genus Coptopsylla Jordan \& Rothschild, 1908 (Siphonaptera: Coptopsyllidae).J Med Entomol.1972;9(3):205-11.

8. Klein JM. [New Fleas (Insecta, Siphonaptera) of Iran. Iv]. French Bull Soc Pathol Exot Filiales. 1963;56:550-4.

9. Laudisoit A, Leirs $H$, Makundi RH, Van Dongen S, Davis $S$, Neerinckx S, et al. Plague and the human flea, Tanzania. Emerg Infect Dis. 2007;13(5):687-93.

10. Dominguez-Penafiel G, Gimenez-Pardo C, Gegundez M, Lledo L. Prevalence of ectoparasitic arthropods on wild animals and cattle in the Las Merindades area (Burgos, Spain). Parasite. 2011;18(3):251-60.

11. Davis S, Makundi RH, Machang'u RS, Leirs H. Demographic and spatio-temporal variation in human plague at a persistent focus in Tanzania. Acta Trop. 2006;100(1-2):133-41.

12. Kaal JF, Baker K, Torgerson PR. Epidemiology of flea infestation of ruminants in Libya. Vet Parasitol. 2006;141(3-4):313-8.

13. Haddadzadeh HR, Sheikh Abbasi Z. A report of prevalence and adaptability of Pulex irritans in a breeder farm around Tehran. Facul Vet Med UnivTehran. 2000;55(2):67-8.

14. Neaman V, Mohammadi GH. Identification the sheep fleas of Isfahan Province. Proceeding of the 7th national and 2nd regional congress of parasitology and parasitic diseases in Iran.Tehran : Tehran University of Medical Sciences; 2010. 